\title{
Protein Phosphatase Slingshot Homolog 1
}

National Cancer Institute

\section{Source}

National Cancer Institute. Protein Phosphatase Slingshot Homolog 1. NCI Thesaurus.

Code C115079.

Protein phosphatase Slingshot homolog $1(1049 \mathrm{aa}, \sim 116 \mathrm{kDa}$ ) is encoded by the human SSH 1 gene. This protein plays a role in the modulation of both protein phosphorylation and cellular projection formation. 